Brit. J. vener. Dis. (1956), 32, 94.

\title{
CHARACTERISTICS OF RESISTANCE OR SUSCEPTIBILITY OF TREPONEMA PALLIDUM TO UNFAVOURABLE FACTORS $* \dagger$
}

\author{
BY \\ L. J. BOREL \\ Hôpital St. Lazare, Paris
}

When a routine TPI test does not show enough immobilization (low titre of syphilitic control serum), it is usual to say that the complement has been partially destroyed or that its action has been stopped by the antigen ; on the other hand, when immobilization is excessive, it is said that the antigenic suspension has been contaminated by antibody coming from the rabbit. In the first case, one speaks of "inhibiting properties of the antigen for the complement", in the second of " sensitization in vivo" of the $T$. pallidum. We are convinced that these opinions should be revised, if the following criteria described by Nelson and Diesendruck (1951) are observed :

(i) Harvesting of the Treponema pallidum one to three days after the clinical appearance of the early acute orchitis ;

(ii) Sufficient quantity of fresh active complement introduced in the reaction mixtures (a good residual haemolysis must be detected after the end of the reaction);

(iii) Constant optimum temperature $\left(35^{\circ} \mathrm{C}\right.$.) ;

(iv) Incubation for at least 18 to 22 hours.

If the titre of the syphilitic reference serum is too low or too high, when these conditions are respected, it is necessary to seek other causes than the preceding ones. It was found that any factor increasing the metabolism of the $T$. pallidum increases its susceptibility to any aggression, and that any factor reducing the metabolism of the $T$. pallidum similarly increases its resistance to any aggression.

\section{Method}

In the following experiments the technique described by Nelson and Mayer (1949) for the routine TPI test was used. Working always in the same experimental conditions, it is easy to notice that the slope of the immobilization curve is constant. Recording the results

* Received for publication March 5, 1956.

† Address given to M.S.S.V.D. on February 24, 1956. on a graph showed (on the conventional scale used) that the angle of this slope is always about $68^{\circ}$. This angle is constant if the immobilization is induced by antibody or any toxic substance. Variations of this angle reveal changes in the metabolism of the germ.

\section{Results}

In a preliminary study of the variations of this slope, two substances were used : chlorpromazine was found to reduce the metabolism of Treponema pallidum, while with "Cocarboxylase" the increased metabolism resulted in a slope of $75^{\circ}$.

When added to a syphilitic control serum these two substances decrease or increase the specific immobilization (controlled by the usual titre of the serum). It is worth noting that these substances are inactive against complement when introduced in a haemolysis reaction (they do not modify the positivity of the reaction).

In further experiments, the metabolism of $T$. pallidum was changed by performing the reaction at different temperatures. The resistance of the organisms to the aggressive factor was found to be considerably higher when the temperature was below $35^{\circ} \mathrm{C}$. These assays were performed with three kinds of toxic substances : arsenic (sulpharsphenamine), antibody, and penicillin. The results were comparable for all three.

In the antibody experiment, as complement does not work at low temperatures, the mixtures of antigen + antibody were pre-sensitized at $5^{\circ}, 15^{\circ}$, $25^{\circ}$, and $35^{\circ} \mathrm{C}$. for $22 \mathrm{hrs}$ and complement was then added and allowed to act at $35^{\circ} \mathrm{C}$. for $22 \mathrm{hrs}$. The jar incubated at $5^{\circ} \mathrm{C}$. showed no difference from a regular TPI test performed in $22 \mathrm{hrs}$ without presensitization. This demonstrates the resistance of $T$. pallidum to the antibody at low temperatures. In the arsenic and penicillin experiments the reaction was carried out with a routine $22 \mathrm{hrs}$ incubation. As shown in the Table, the doses necessary to produce 50 per cent. immobilization are markedly higher in cold conditions. 
TABLE

RESISTANCE OF T. PALLIDUM TO Ab-As-PENICILLIN AT DIFFERENT TEMPERATURES OF INCUBATION

\begin{tabular}{|c|c|c|c|}
\hline \multirow{2}{*}{$\begin{array}{c}\text { Temperatures } \\
\text { of } \\
\text { Incubation } \\
\left({ }^{\circ} \mathrm{C} .\right)\end{array}$} & \multirow{2}{*}{$\begin{array}{c}50 \text { per cent. } \\
\text { Titre (after } \\
22 \text { hrs pre-sensi- } \\
\text { tization) }\end{array}$} & \multicolumn{2}{|c|}{$\begin{array}{l}\text { Dose giving } 50 \text { per cent. } \\
\text { Immobilization in } 22 \mathrm{hrs}\end{array}$} \\
\hline & & $\begin{array}{l}\text { Penicillin } \\
\text { (mg./ml.) }\end{array}$ & $\begin{array}{c}\text { Sulphars- } \\
\text { phenamine } \\
\text { (mg./ml.) }\end{array}$ \\
\hline $\begin{array}{r}5 \\
15 \\
25 \\
35\end{array}$ & $\begin{array}{r}360 \\
560 \\
940 \\
2,400\end{array}$ & $\begin{array}{l}1 \cdot 2 \\
1.2 \\
0 \cdot 3 \\
0.06\end{array}$ & $\begin{array}{r}500 \\
250 \\
20 \\
9\end{array}$ \\
\hline
\end{tabular}

This Table shows that the doses of toxic agent necessary to give 50 per cent. immobilization are more than ten times higher at $5^{\circ} \mathrm{C}$. than at $35^{\circ} \mathrm{C}$.

\section{Summary}

Preliminary experiments to solve problems set by the TPI test are reported. Certain factors which are able to modify the resistance or the susceptibility of the $T$. pallidum to immobilization have been noted. It is possible that many other factors able to produce the same effects may be found in the antigenic suspension, and further studies of this problem will be reported later.

\section{REFERENCES}

Nelson, R. A., and Diesendruck, J. A. (1951). J. Immunol., 66, 667 -, and Mayer, M. M. (1949). J. exp. Med., 89, 369. 